\title{
Materials Indistinguishable from Iodotyrosines in Normal Human Serum and Human Serum Albumin*
}

\author{
Henry Weinert, Hideo Masui, Ildiko Radichevich, and Sidney C. Werner † \\ (From the Department of Medicine, Columbia University College of Physicians \& Surgeons, \\ and the Presbyterian Hospital, New York, N. Y.)
}

\begin{abstract}
Summary. Materials indistinguishable from authentic mono- and diiodotyrosines were identified in extracts of normal human serum as well as in extracts of purified human serum albumin. These materials were not found in association with the other serum proteins. Identification of MIT and DIT was made by a technique using rechromatography to constant specific activity, as well as by the Barker wet ash distillation method, which established the compounds in question as being iodinated ones. By two different extraction and chromatographic methods we estimated the amounts of both MIT and DIT present in normal human serum or albumin; the estimates were in good agreement. These compounds together constituted between $19 \%$ and $25 \%$ of the extractable serum iodine.
\end{abstract}

\section{Introduction}

A controversy has existed about the claim that iodotyrosines constitute a sizable fraction of the iodine extractable from normal human serum. Trevorrow suggested approximately 30 years ago that iodotyrosine, L-thyroxine, and iodide (1) could be identified in chemical extracts of human serum. Wilmanns made a similar observation in the rat (2). However, Tong, Taurog, and Chaikoff failed to demonstrate these compounds; they showed that iodotyrosines added to rat serum were poorly bound by the proteins and rapidly disappeared from the circulation after injection (3). This rapid deiodination was confirmed shortly thereafter by Fletcher, Litvak, and Stanbury. The kinetic considerations raised by their experiments led them to postulate that the iodine turnover thus necessary was greatly in excess of the normal level of secretory activity in the thyroid (4).

\footnotetext{
* Submitted for publication December 19, 1966; accepted April 13, 1967.

Aided by grants AM-00008 (C14-18 inc.) from the $\mathrm{Na}$ tional Institute of Arthritis and Metabolic Diseases.

$\dagger$ Address requests for reprints to Dr. Sidney C. Werner, Dept. of Medicine, Columbia University College of Physicians \& Surgeons, 630 W. 168th St., New York, N. Y. 10032.
}

Upon the introduction of radioactive iodine as an investigative tool, labeled compounds were found to be regularly absent from the iodotyrosine areas of serum chromatograms except in intrinsic thyroid disease (5-14). This evidence, plus the kinetic considerations already mentioned, led to the doctrine that the serum iodine consisted essentially of thyroxine $\left(\mathrm{T}_{4}\right)$, triiodothyronine $\left(\mathrm{T}_{3}\right)$, and iodide $\left(\mathrm{I}^{-}\right)$.

In 1959 Werner and Block reopened the question (15). They demonstrated that ${ }^{127}$ I-labeled iodotyrosines were present in relatively high concentrations on chromatograms prepared from hot acid $n$-butanol extracts (16) of normal human serum, whereas, despite ${ }^{131} \mathrm{I}$ administration, no corresponding labeled compounds were found on the same chromatograms (15). Similar results were obtained in the rat (17).

To explain these findings, it was originally suggested that DIT and MIT existed free in the serum (15). This hypothesis was abandoned in light of the rapid disappearance of the free compounds from the circulation in man (18) as well as in the rat, and the proposal was made that these compounds were derived on extraction from a labile precursor (17).

Since then numerous reports have appeared in support of, or in denial of, these claims. The sug- 
gestion was offered that the findings were artefacts of the extraction and colorimetric methods employed $(19,20)$. However, evidence has been presented to deny such an explanation $(21,22)$.

A number of experiments using a variety of chromatographic procedures failed to reveal any ${ }^{12 \pi} \mathrm{I}$-labeled iodotyrosines in normal serum preparations (23-26). Nauman repeated much of this previous work, however, and demonstrated that iodotyrosines were present (27). He suggested, on the basis of recovery data, that certain methods giving negative results, such as the column chromatographic technique with Dowex 1-RX2 (28), gave yields too low to permit ready detection of iodotyrosines. Further confirmation has come from Arosenius (29), who found both MIT and DIT in normal human serum, although in half the amounts estimated by Werner and Block.

The use of thermal neutron activation to establish the presence of iodine in the suspected iodotyrosine compounds has led to equally positive conclusions (30-33). However, efforts to label iodotyrosines in vivo have been uniformly unsuccessful (34-37) until very recently $(38,39)$.

Considerable doubt thus still prevails as to whether the compounds in the MIT and DIT areas of chromatograms are truly mono- and diiodotyrosine. Moreover, the form in which these compounds, if present, circulate, has not yet been established.

The results of the present study establish that two materials, each indistinguishable from MIT and DIT, are present in normal human serum and circulate with the albumin fraction.

\section{Methods}

Blood was obtained from fasting healthy students and drawn with a Fenwal blood transfer set directly into 50-ml centrifuge tubes. The blood was allowed to clot at room temperature for 5 hours, and the serum separated. Sera were not used if there was evidence of hemolysis or of high fat content. Sera were processed the same day or stored at $-20^{\circ} \mathrm{C}$ for a period of not more than 14 days. No antithyroid drugs or preservatives were employed, although our addition of antithyroid drug to serum to prevent deiodination does not influence the presence or amounts of iodotyrosines detected (40).

Serum protein fractionation. Protein fractionation of $100-\mathrm{ml}$ amounts of serum was accomplished by the method of Porath (41). The serum was layered on ethanolized cellulose suspended in Tris-maleate buffer $(\mathrm{pH}$ 8.6) in a column. Electrophoresis was carried out for 7 days at a constant current of $325 \mathrm{~mA}$. Two modifications of the standard procedure were made. First, electrophoresis was carried out at $5^{\circ} \mathrm{C}$ in darkness to minimize deiodination. Second, a Milton-Roy Minipump was used during countercurrent elution of the fractions from the column. This pump fed the countercurrent buffer at a slightly greater rate than the calculated rate of displacement by the fastest migrating protein component in order to ensure efficient elution of protein fractions without excessive dilution by buffer.

Smaller quantities of serum (20 to $30 \mathrm{ml}$ ) were fractionated by means of a DEAE-Sephadex G-50 (medium grade) column. ${ }^{1}$ Before application onto the column, the serum sample was dialyzed for 12 hours against a tenfold volume of the sodium phosphate buffer, the same as that used in the column $(\mathrm{pH} 6.6,0.02 \mathrm{M})$. The equilibrated sample was then applied to the column $(2 \times 30$ $\mathrm{cm}$ ) and the first fraction eluted with the same buffer. Elution of subsequent fractions was accomplished with the addition to the phosphate buffer of an $\mathrm{NaCl}$ gradient varying from an initial concentration of 0.09 mole per $\mathrm{L}$ to a final one of 0.16 mole per L. Fractions for all column procedures were collected in $10-\mathrm{ml}$ portions with a Vanguard volumetric fraction collector.

Routine electrophoresis of the serum proteins on paper was conducted with barbital buffer $(\mathrm{pH} 8.6$, ionic strength 0.075 ) at a constant current of $0.35 \mathrm{~mA}$ per strip for 16 hours. Protein bands were made visible with bromophenol blue. Further identification of protein fractions was made by immunoelectrophoresis performed according to the method of Grabar and Williams (42). Goat antihuman serum ${ }^{2}$ was added to the trough and the plate developed over a period of 24 to 48 hours. Determinations of protein concentrations were made by means of the Folin-Ciocalteau method (43) adapted for a Technicon Autoanalyzer.

When it was found necessary to concentrate small portions of protein fractions before these identification procedures, a Schleicher \& Schuell ultrafilter assembly was used. Concentration of large volumes of protein fractions was accomplished by flash evaporation with a Rinco heavy duty evaporator at $38^{\circ} \mathrm{C}$ and a vacuum of approximately $0.2 \mathrm{~mm} \mathrm{Hg}$. This enabled us to reduce the volume by $75 \%$ without protein precipitation.

Extraction procedures. The hot acid butanol method (method I) of Mandl and Block (44) was used for iodoamino acid extraction without change (Figure 1). To demonstrate whether similar results could be obtained by an alternative method, we utilized a modification of the extraction method proposed by West, Chavre, and Wolfe for serum thyroxine determinations (45) (Figure 1).

The major advantage of the modified procedure is that only two evaporations are necessary, and both are rapid due to the relatively volatile characteristics of the solvents utilized. It is essential to the efficiency of extraction that only spectroanalyzed acetone be employed, acidified just before use. Removal of lipids and salts from

1 We are indebted to Dr. Kiyoshi Miyai for performing the fractionations.

2 Hyland Laboratories, Los Angeles, Calif. 
HOT ACID BUTANOL EXTRACTION

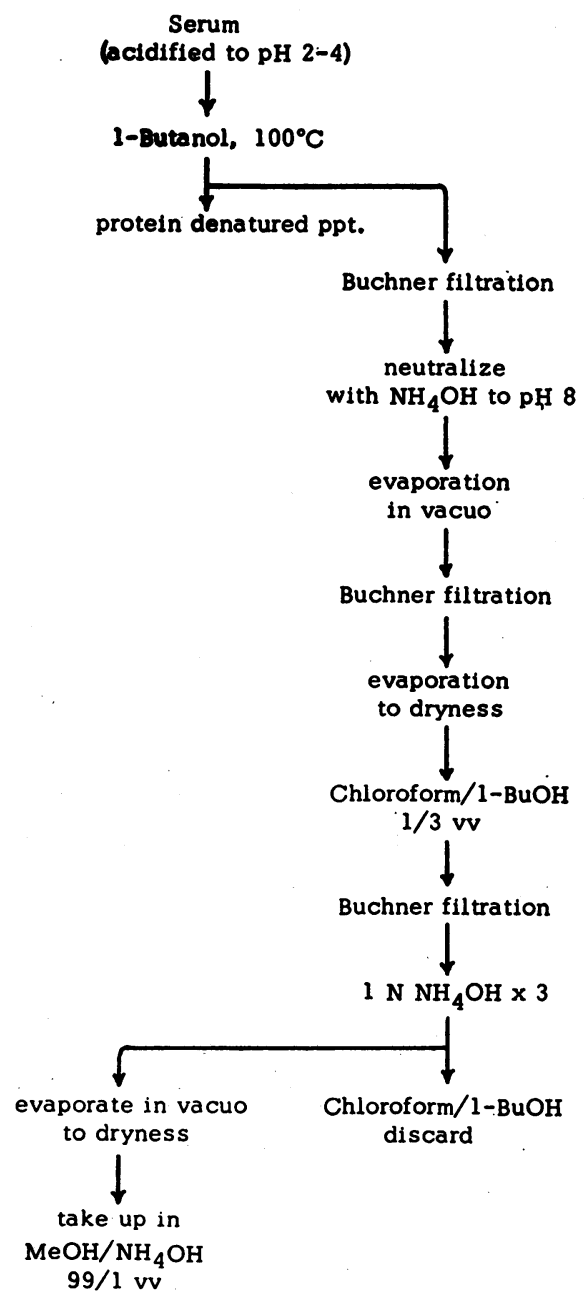

MODIFIED "WEST" EXTRACTION

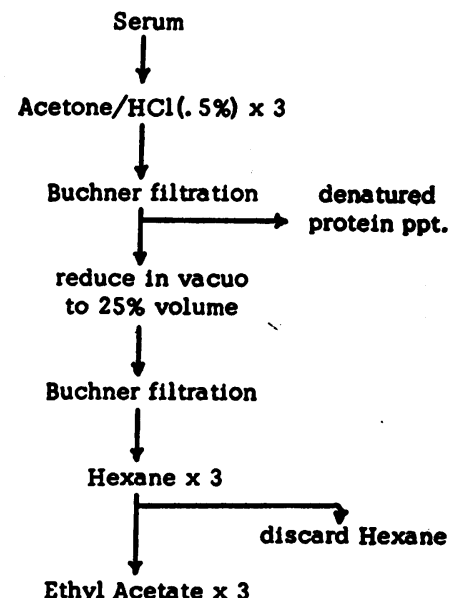

Ethyl Acetate $\times 3$

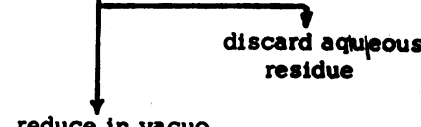

reduce in vacuo

to dryness

$\downarrow_{\text {take up in }}$

$\mathrm{MeOH} / \mathrm{NH}_{4} \mathrm{OH}$

$99 / 1$ vo

Fig. 1. Flow SheEt OF THE TWO METHODS USED IN THE PRESENT EXPERIMENTS to EXTRACT IODOCOMPOUNDS FROM SERUM.

the acetone extract must be done with equal volumes of hexane, since an excess of this solvent readily takes up iodoamine acid with consequent large losses. The final ethyl acetate extract must be dried exhaustively to remove all traces of this solvent. Otherwise, the addition of methanol/NH.OH ( $99 / 1 \mathrm{vol} / \mathrm{vol})$ to acid ethyl acetate results in a white precipitate that interferes with the application of the final extract to the chromatogram.

Since buffer salts when present in high concentration are not completely removed by any method of extraction for iodoamino acids, chromatographic separation of the iodoamino acid is seriously impaired. The protein fractions before extraction were therefore precipitated to remove buffer, with sodium tungstate and $\mathrm{H}_{2} \mathrm{SO}_{4}$ acidifica- tion for their routine protein-bound iodine method (46). An excess of the precipitating reagents was added to the buffer supernatant after centrifugation to verify the completeness of protein precipitation.

Ethyl acetate was redistilled over activated charcoal before use and 2-butanol was distilled over ferrous sulfate. Glassware was adequately washed and rinsed repeatedly with deionized water before use.

Chromatographic procedures. Paper chromatography after method I extraction was conducted in one or two dimensions as previously reported (16). 2- $\mathrm{BuOH} / 3.3 \%$ $\mathrm{NH}_{4} \mathrm{OH}(3 / 1 \mathrm{vol} / \mathrm{vol})$ was used for the first dimension, $n-\mathrm{BuOH} / \mathrm{HAc} / \mathrm{H}_{2} \mathrm{O}(9 / 1 / 2.5 \mathrm{vol} / \mathrm{vol})$ for the second dimension. The first system was always developed by de- 
scending technique; the second was always developed by ascending techniques after turning the paper $90^{\circ}$. Chromatography was conducted over a period of 18 to 22 hours at $25^{\circ} \mathrm{C}$, generally in a Risco Chromatocab.

Thin layer chromatography (TLC) after modified West extraction procedure was performed on Gelman glass fiber sheets impregnated with silica gel. A solvent system was developed in our laboratory for this commercially prepared plate, namely, pyridine/tertiary amyl alcohol $/ n$-butanol $/ \mathrm{NH}_{4} \mathrm{OH} / \mathrm{H}_{2} \mathrm{O} \quad(35 / 140 / 20 / 3 / 13$ vol/ vol). A typical separation of iodoamino acid standards ( $1 \mathrm{mM}$ concentration each) is shown in Figure 2. The usual time of chromatography was 3 hours at $25^{\circ} \mathrm{C}$.

Known concentrations of ${ }^{122} \mathrm{I}$ standards ${ }^{3}$ were run on both sides of the unknown extract, in both TLC and paper chromatography. The standards were made visible after chromatography by the ceric sulfate/arsenious acid spraying technique (44).

${ }^{131} \mathrm{I}$ - or ${ }^{120} \mathrm{I}$-labeled DIT and MIT as standards were obtained commercially. 4 Original specific activities varied with a range for MIT of 18.2 to $26.5 \mu \mathrm{c}$ per $\mu \mathrm{g}$ and for DIT 12.7 to $21.3 \mu \mathrm{c}$ per $\mu \mathrm{g}$. All labeled compounds were chromatographed for purity before use and rechromatographed when necessary.

Pure ${ }^{131} \mathrm{I}$ - or ${ }^{125} \mathrm{I}$-labeled DIT and MIT, or $\mathrm{T}_{4}$, was used to obtain recovery data and to locate and identify the iodine-containing areas on the developed chromatograms. The amount of isotope added varied according to specific activity of the standard materials, care being taken to add less stable standard than could possibly interfere with the reliability of the colorimetric determinations. The greatest amount of labeled MIT used was $0.85 \mu \mathrm{c}$ and of labeled DIT $0.41 \mu \mathrm{c}$. Thus less than $0.05 \mu \mathrm{g}$ stable carrier was introduced.

After initial identification of radioactive peaks on the chromatogram by beta strip counting (Vanguard gas flow strip counter), the areas of interest were cut out and radioactivity was counted to $95 \%$ accuracy in a Packard autogamma well counter. Radioautographs were also made to indicate location of radioactivity on the chromatograms when two dimensional or isotope dilution techniques were employed to identify unknown materials, and the chromatogram was marked by visual comparison to correspond with the exposed areas. The appropriate areas of the chromatogram were then counted as above, to $95 \%$ accuracy.

When recovery data were being obtained, appropriate standards labeled with ${ }^{125} \mathrm{I}$ were added before protein fractionation and additional IsI-labeled standards were introduced before extraction or before chromatography.

Iodimetric procedures. Colorimetric determination of the iodine-containing materials on the final chromatogram was made as previously described by this laboratory (17). In the present work, however, fading was recorded continuously (Bausch and Lomb Spectronic 20 data acquisition system). Measurements were made at wavelength $420 \mathrm{~m} \mu$, and fading was recorded over a pe-

\footnotetext{
${ }^{3}$ Mann Research Laboratories, New York, N. Y.
}

4 Abbott Laboratories, Chicago, I11.

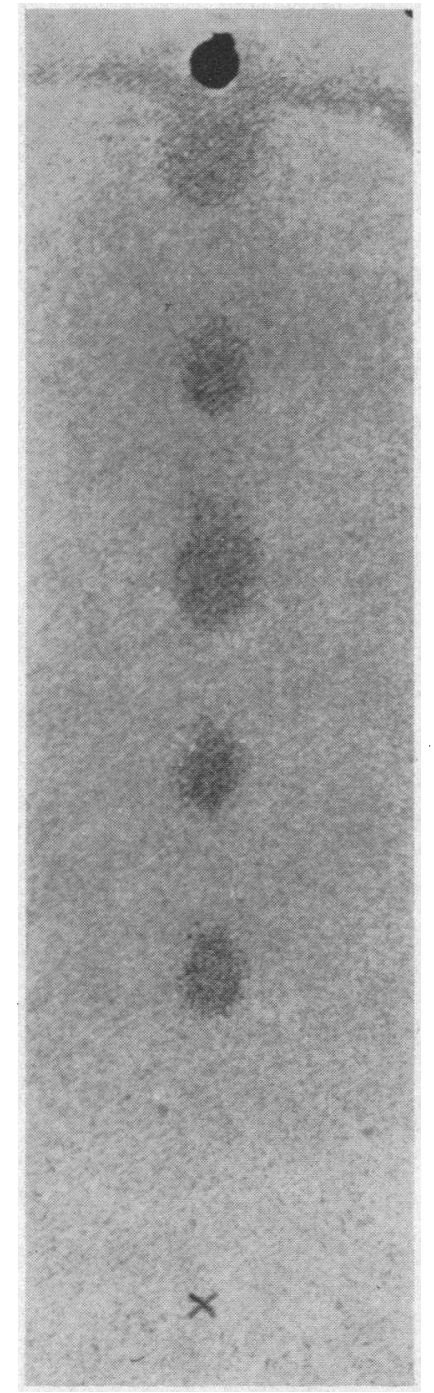

Fig. 2. Separation of Standard IODOAMINo ACIDS IN 1 MM CONCENTRATION BY THIN LAYER CHROMATOGRAPHY (SEE TEXT) SUBSEQUENT TO MODIFIED WEST EXTRACTION PROCEDURE. From origin $(X)$ the compounds separated in the order of diiodotyrosine, monoiodotyrosine, thyroxine, triiodothyronine, and iodide.

riod of 10 minutes by a Bausch and Lomb V.O.M.-5 recorder.

The identity of the compound causing fading of the ceric sulfate/arsenious acid system was further established as an iodinated one by use of the wet ash method of Barker (46). In this procedure, organic material in the chromatographic samples is digested and iodine, probably as $\mathrm{HI}$, distilled from the reaction mixture before colorimetric determination.

Areas of the chromatograms without known iodine activity were tested concurrently with the areas thought to contain iodine. Blank readings were made from an 
area of equal size to that of the standards, and calculated iodine content did not exceed $0.04 \mu \mathrm{g}$. Colorimetric assay was conducted on $30 \%$ of the distillate from each of the unknown and blank areas, as well as from a series of concentrations of standard iodine solution as sodium iodide. Figure 3 shows a typical calibration curve for the Barker method. The range on the colorimetric scale at which test readings were made is also illustrated in Figure 3.

Specific activity determination. Preliminary experiments were made to identify stable DIT and MIT in the appropriate areas of chromatograms by means of rechromatography to constant specific activity. They revealed that a simple procedure was not adequate. Both compounds underwent $3 \%$ to $5 \%$ deiodination upon elution from paper. Since iodide reacts almost twice as fast in the Sandell-Kolthoff system as MIT or DIT, falsely high values for the latter are obtained. Thus, MIT or DIT, and iodide appear in the eluate from the initial chromatographic area. On the other hand, the isotopic standard added to this eluate for isotope dilution purposes is $98 \%$ pure.

To obtain equal rates of deiodination for both labeled MIT or DIT standard solutions and the eluates of the MIT or DIT areas, we added the appropriate labeled standard to the eluted MIT or DIT material. The mixtures were then chromatographed two dimensionally on paper. Elution of the radioactive areas then entailed equal deiodination of ${ }^{127} \mathrm{I}$ and ${ }^{181} \mathrm{I}$ compounds. Thus samples of the eluates could be measured and the remainder applied to paper for a second two dimensional separation with the expectation that specific acivity would remain constant if MIT or DIT was truly present in the original extracts. The DIT and MIT areas of the second two dimensional chromatograms were thus again tested

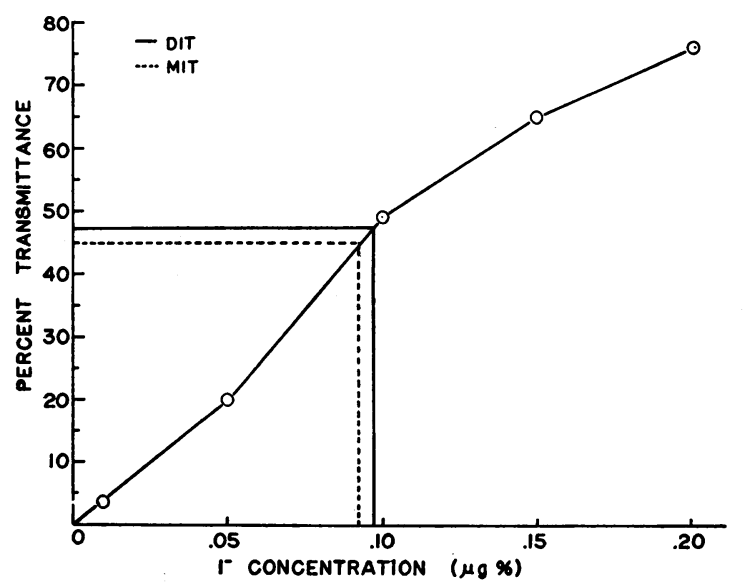

Fig. 3. Representative calibration curve of iNCREASING AMOUNTS OF IODIDE IN COLORIMETRIC STEP OF BARKER WET ASH METHOD. Extrapolation of values for eluates from monoiodotyrosine (MIT) and diiodotyrosine (DIT) areas of chromatograms of serum extracts illustrates the representative concentrations at which all these unknown compounds were determined.
TABLE I

Identification of iodotyrosines extracted from two separate normal human sera: final two dimensional chromatography and isotope dilution*

\begin{tabular}{|c|c|c|c|c|c|c|}
\hline \multirow[b]{2}{*}{$\underset{\text { Serum }}{\text { no.t }}$} & \multirow[b]{2}{*}{$\begin{array}{l}\text { Com- } \\
\text { pound }\end{array}$} & \multirow{2}{*}{$\begin{array}{c}127 \mathrm{I} \\
\text { colori- } \\
\text { metry } \ddagger\end{array}$} & \multirow{2}{*}{$\begin{array}{c}181 \mathrm{I} \\
\text { radio- } \\
\text { activity } \ddagger\end{array}$} & \multirow[b]{2}{*}{ SA } & \multicolumn{2}{|c|}{$\begin{array}{c}\text { Applied SA/ } \\
\text { Recovered SA }\end{array}$} \\
\hline & & & & & Ratio & $\begin{array}{c}\% \\
\text { Difference }\end{array}$ \\
\hline I & & 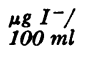 & $\stackrel{\mu c /}{100} \mathrm{ml}$ & $\stackrel{\mu c /}{\mu g} I^{-}$ & & \\
\hline $\begin{array}{r}\mathrm{A} \\
1 \\
2\end{array}$ & MIT & $\begin{array}{l}0.42 \\
0.37\end{array}$ & $\begin{array}{l}0.600 \\
0.543\end{array}$ & $\begin{array}{l}1.425 \\
1.466\end{array}$ & 0.972 & 3 \\
\hline${ }^{B} \begin{array}{r}1 \\
2\end{array}$ & DIT & $\begin{array}{l}0.32 \\
0.28\end{array}$ & $\begin{array}{l}0.392 \\
0.361\end{array}$ & $\begin{array}{r}1.250 \\
1.288\end{array}$ & 0.970 & 3 \\
\hline $\begin{array}{ll}\text { II } & \\
& \text { A } \\
& 1 \\
& \mathbf{2}\end{array}$ & MIT & $\begin{array}{l}0.60 \\
0.55\end{array}$ & $\begin{array}{l}0.594 \\
0.583\end{array}$ & $\begin{array}{l}0.990 \\
1.060\end{array}$ & 0.933 & 6 \\
\hline $\begin{array}{l}B_{1} \\
\quad 2\end{array}$ & DIT & $\begin{array}{l}0.41 \\
0.36\end{array}$ & $\begin{array}{l}0.414 \\
0.392\end{array}$ & $\begin{array}{l}1.009 \\
1.089\end{array}$ & 0.926 & 7 \\
\hline
\end{tabular}

* All values refer to original $100 \mathrm{ml}$ normal human serum.

$\dagger 1=$ MIT (monoiodotyrosine) DIT (diiodotyrosine) material eluted from first two dimensional system, and applied to second two dimensional system. $2=$ MIT or DIT material eluted from second two dimensional system.

$\ddagger$ Ten-minute colorimeter reading, all readings made in the range of between $12 \%$ and $50 \%$ transmittance; counting range for ${ }^{121} I$ in portions of from $20 \%$ to $50 \%$ of original eluate was between 20,000 and 50,000 cpm.

for ${ }^{127} \mathrm{I}$ and ${ }^{181} \mathrm{I}$ and compared to the specific activities previously obtained. The same procedure was employed for the standard labeled compounds, and although specific activity was seemingly unaltered, there was too little stable carrier to permit a sound estimate. The rates of deiodination of standard radioactive iodotyrosines were similar to those seen in the experiments with serum materials. This procedure ${ }^{5}$ was utilized in all our specific activity experiments.

\section{Results}

The isotope dilution procedure was employed to identify MIT and DIT not only in extracts of normal human serum, but also in an extract of a pure albumin fraction prepared from normal serum.

Normal human serum. The results of the two isotope dilution experiments conducted on extracts of $100 \mathrm{ml}$ normal human serum, with repeated two dimensional chromatography, are presented in Tables $I$ and V (sera I and II). The specific activity of the eluates from the first two dimensional chromatogram and the specific activity of the final eluate differ by a maximum of $7 \%$. This was true for both the DIT and MIT areas.

\footnotetext{
${ }^{5}$ Suggested by Dr. Jacob Robbins of the National Institutes of Health.
} 
The specific activities of iodide in the iodide areas of the chromatograms also were almost identical initially and finally. As stated earlier, iodide resulted from deiodination of MIT or DIT in the course of elution.

Purified albumin fraction. Four experiments were performed in which $100 \mathrm{ml}$ of normal human serum was separated into protein fractions by column electrophoresis in the Porath apparatus. The presence of DIT and MIT in extracts of the protein fractions was confirmed in one experiment by the specific activity procedure above. The presence of iodine in the compounds in question was established in two experiments by wet ashing and distillation according to the method of Barker.

In the first experiment of the four, $100 \mathrm{ml}$ of normal human serum (serum III) was fractionated. $^{6}$ The protein fractions were eluted by gravity, and a good separation of all major protein components was achieved. Thyroxine- ${ }^{131} \mathrm{I}$ added to the serum before fractionation was distributed among the serum proteins as described for paper electrophoresis.

Each protein fraction was extracted by method I and chromatographed. The distribution of iodoamino acids is listed in Table II. MIT and DIT were found only in the albumin fraction. Values have been corrected for losses and presented as micrograms per $100 \mathrm{ml}$ original serum. Losses averaged $41 \%$ for this procedure as estimated from recovery of $\mathrm{T}_{4}{ }^{-131} \mathrm{I}$ added to the original serum before handling. Losses in the extraction and chromatographic procedures of labeled MIT and DIT are entirely comparable to those of labeled $\mathrm{T}_{4}$ (see Discussion). No labeled iodotyrosines were produced as a result of the over-all procedure, or with ${ }^{131} \mathrm{I}$-labeled albumin similarly processed.

The next three experiments (sera IV, V, and VI) were limited to the albumin fraction obtained from $100 \mathrm{ml}$ normal human serum. Isolation and identification were conducted of the compounds thought to be DIT and MIT in the extracts of these albumin fractions. In this phase of the study, the protein fractions were eluted from the Porath column by the countercurrent technique described under Methods, thereby providing higher resolution among the proteins. In the ex-

\footnotetext{
${ }^{6}$ With the assistance of Dr. Jack Oppenheimer and co-workers, Montefiore Hospital, New York, N. Y.
}

TABLE II

Iodoamino acids in extracts of protein fractions prepared from $100 \mathrm{ml}$ normal human serum (Porath): serum I

\begin{tabular}{|c|c|c|c|c|c|c|}
\hline \multirow[b]{2}{*}{ Fraction* } & \multirow[b]{2}{*}{ MIT } & \multirow[b]{2}{*}{ DIT } & \multirow[b]{2}{*}{$T_{4}$} & \multirow[b]{2}{*}{$T_{3}$} & \multicolumn{2}{|c|}{$\begin{array}{l}\text { Total iodo- } \\
\text { amino acids }\end{array}$} \\
\hline & & & & & $\begin{array}{l}\text { Iodocom- } \\
\text { pounds }\end{array}$ & $\underset{\text { PBI† }}{\text { Routine }}$ \\
\hline & & \multicolumn{2}{|c|}{$\mu g I^{-} / 100 \mathrm{ml}$} & & & \\
\hline $\begin{array}{l}\text { Prealbumin } \\
\text { Albumin } \\
\alpha \text {-Globulin } \\
\beta-\text {-Globulin } \\
\gamma \text {-Globulin }\end{array}$ & 0.75 & 0.69 & $\begin{array}{l}0.87 \\
0.30 \\
2.30\end{array}$ & 0.15 & & \\
\hline Total & 0.75 & 0.69 & 3.47 & 0.15 & 5.06 & 5.8 \\
\hline
\end{tabular}

* All protein fractions contained a single component upon immunoelectrophoresis, except $\alpha$-globulin, which had $10 \%$ albumin.

$+\mathrm{PBI}=$ protein-bound iodine.

periment with serum IV, the isotope dilution procedure was again employed. The presence and identity of MIT and DIT in the albumin fraction were again confirmed (Table III).

In the experiment with serum $\mathrm{V}$, protein precipitation and dialysis (48 hours) against saline of a portion of the albumin fraction from the Porath column were employed to establish whether DIT- ${ }^{127} I$ and MIT- ${ }^{127} \mathrm{I}$ were present in free or bound form. Neither compound could be detected in the dialyzate. Dialyzed and undialyzed albumin fractions were subjected to extraction and chromatography by method I, but also by a modified West method of extraction followed by a thin layer chromatographic procedure (see Methods). The results revealed the presence of iodocompounds in comparable amounts in the MIT and DIT areas by both procedures; MIT $0.68 \mu \mathrm{g}$

\section{TABLE III}

Identification of iodotyrosines extracted from $100 \mathrm{ml}$ norma human serum albumin: final two dimensional chromatography and isotope dilution*

\begin{tabular}{|c|c|c|c|c|c|c|}
\hline \multirow[b]{2}{*}{$\underset{\text { no.t }}{\text { Serum }}$} & \multirow[b]{2}{*}{$\begin{array}{l}\text { Com- } \\
\text { pound }\end{array}$} & \multirow{2}{*}{$\begin{array}{l}{ }^{127} \mathrm{I} \\
\text { colori- } \\
\text { metry } \ddagger\end{array}$} & \multirow{2}{*}{$\begin{array}{c}121 \mathrm{I} \\
\text { radio- } \\
\text { activity } \ddagger\end{array}$} & \multirow[b]{2}{*}{ SA } & \multicolumn{2}{|c|}{$\begin{array}{c}\text { Applied SA/ } \\
\text { Recovered SA }\end{array}$} \\
\hline & & & & & Ratio & $\begin{array}{c}\% \\
\text { Difference }\end{array}$ \\
\hline III & & ${ }_{100}^{\mu g} \mathrm{ml}^{-/}$ & $\stackrel{\mu \mathrm{c} /}{100 \mathrm{ml}}$ & $\underset{\mu g}{\mu C /} I^{-}$ & & \\
\hline $\begin{array}{l}\text { A }_{1} \\
\quad 2\end{array}$ & MIT & $\begin{array}{l}0.69 \\
0.61\end{array}$ & $\begin{array}{l}0.852 \\
0.806\end{array}$ & $\begin{array}{l}1.235 \\
1.321\end{array}$ & 0.935 & 6.5 \\
\hline $\begin{array}{l}B_{2} \\
2\end{array}$ & DIT & $\begin{array}{l}0.52 \\
0.48\end{array}$ & $\begin{array}{l}0.397 \\
0.371\end{array}$ & $\begin{array}{l}0.763 \\
0.773\end{array}$ & 0.987 & 1.3 \\
\hline
\end{tabular}

* Per $100 \mathrm{ml}$ means as calculated for $100 \mathrm{ml}$ original serum.

$\dagger 1=$ MIT or DIT material eluted from first two dimensional system $\dagger 1=M I T$ or DIT material eluted from first two dimensional system,
and applied to second two dimensional system. $2=$ MIT or DIT
material eluted from second two dimensional system:

material eluted from second two dimensional system: $\ddagger$ All colorimeter readings between $12 \%$ and $50 \%$ transmittan
radioactivity counting rates between 100,000 and $250,000 \mathrm{cpm}$. 
per $100 \mathrm{ml}$ (method I) and $0.82 \mu \mathrm{g}$ per $100 \mathrm{ml}$ (West) ; and DIT $0.56 \mu \mathrm{g}$ per $100 \mathrm{ml}$ (method I) and $0.68 \mu \mathrm{g}$ per $100 \mathrm{ml}$ (West). The presence of iodine in these compounds was further verified by the results from the Barker wet ash method. The fact that these compounds were protein bound and not free was confirmed twice by dialysis, since no MIT or DIT was recovered from the dialyzates.

The experiment with serum VI was designed to quantitate the losses resulting from the over-all procedure, in order to establish whether the MIT and DIT iodine values determined for the original serum, and the values determined for the albumin fraction, corresponded. Protein-bound iodine values were also determined and compared. Thyroxine- ${ }^{125} \mathrm{I}$ labeled in the 3 - or 5 -position was added to the serum before processing (see above). Labeled DIT and MIT were not added since the free compounds do not bind reliably with the albumin fraction and wash through the column during electrophoresis. L-Triiodothyronine was not used as a labeled standard since the amount of $T_{3^{-}}$ ${ }^{127} \mathrm{I}$ normally present in serum approximates 0.2 to $0.4 \mu \mathrm{g}$ per $100 \mathrm{ml}$, and thus could not account for the total value of $1.5 \mu \mathrm{g}$ per $100 \mathrm{ml} \mathrm{MIT}$ and $\mathrm{DIT}$, or more, found in the present experiments. Figure 4 illustrates the separation of serum proteins achieved and the distribution of added thyroxine- ${ }^{125} \mathrm{I}$.

After protein precipitation of the albumin fraction and addition of ${ }^{131}$ I-labeled MIT and DIT standards to the precipitate, the precipitated material was extracted by method I or by the modi-

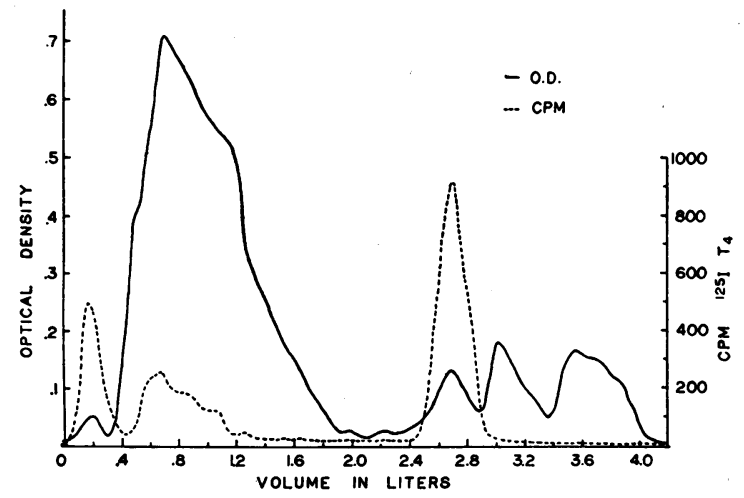

Fig. 4. Protein concentrations and distributions OF RADIOACTIVITY AFTER THYROXINE- ${ }^{125} \mathrm{I}$ WAS ADDED TO the STARTINg SERUM Before Porath COLUMN EleCtroPHORESIS AND COUNTERCURRENT ELUTION.
TABLE IV

Procedural losses of ${ }^{127}$ I and ${ }^{131}$ I compounds

\begin{tabular}{|c|c|c|c|}
\hline \multirow[b]{2}{*}{ Procedure } & \multicolumn{3}{|c|}{ Per cent loss } \\
\hline & $\mathrm{PB}^{127} \mathrm{I}^{*}$ & $\mathrm{~T}^{125 \mathrm{I}}$ & MIT $^{181} I_{I}$ \\
\hline Porath electrophoresis & & 7 & \\
\hline Protein precipitation & & 5 & \\
\hline $\begin{array}{l}\text { Extraction of iodoamino acids } \\
\text { Method I } \\
\text { Modified West }\end{array}$ & & $\begin{array}{l}17 \\
14\end{array}$ & $\begin{array}{l}15 \\
13\end{array}$ \\
\hline $\begin{array}{l}\text { Chromatography of extracts } \\
\text { Paper chromatogram } \\
\text { Thin layer chromatogram }\end{array}$ & & $\begin{array}{l}3 \\
2\end{array}$ & $\begin{array}{l}4 \\
3\end{array}$ \\
\hline $\begin{array}{l}\text { Elution from chromatogram } \\
\text { Paper chromatogram } \\
\text { Thin layer chromatogram } \dagger\end{array}$ & & $\begin{array}{l}4 \\
0\end{array}$ & $\begin{array}{l}4 \\
0\end{array}$ \\
\hline $\begin{array}{l}\text { Barker wet ash method and distilla- } \\
\text { tion of iodine }\end{array}$ & & 6 & 7 \\
\hline $\begin{array}{l}\text { Total loss } \\
\text { Method I and paper chromatogram } \\
\text { West method and TLC }\end{array}$ & $\begin{array}{l}41 \\
32\end{array}$ & $\begin{array}{l}42 \\
34\end{array}$ & $\begin{array}{l}31 \\
23\end{array}$ \\
\hline
\end{tabular}

* PBI done by Barker method on serum before processing, and compared with Barker determination on final eluates. T-126I was added to original serum before processing. MIT-121 I was added to precipitate of protein fractions.

$\uparrow$ Area to be determined was cut out and placed in combustion flask without elution.

fication of the West extraction procedure described under Methods. Paper chromatography of the method I extract and thin layer chromatography of the West extract yielded two radioactive areas corresponding to MIT-131 I and DIT- ${ }^{-131} \mathrm{I}$. The iodine content of each was then determined by the Barker wet ash method.

Final recovery averaged $59 \%$ of the initially added thyroxine-125 I for method $\mathrm{I}$ and $68 \%$ for the thin layer procedure (Table IV). No ${ }^{125} \mathrm{I}$ labeled MIT or DIT was detected. The calculated values for ${ }^{127} \mathrm{I}$-labeled MIT and DIT after correction for losses are given in Table $\mathrm{V}$ along with the corresponding values for the parent serum.

The purity of the albumin fraction was tested by immunoelectrophoresis. Albumin is seen as the only visible constituent of this fraction (Figure 5).

Before the work with the Porath column, six experiments were performed to separate the serum proteins by DEAE G-50 Sephadex column chromatography. Both DIT and MIT were recovered only from the albumin fractions although DIT was lacking in one of the six experiments. In two experiments, a small amount of $T_{4}$ was also found in the albumin fractions. Otherwise, $\mathrm{T}_{4}$ was found, in all six experiments, with the $\alpha$-globulin. No iodinated compounds were present in the other serum protein fractions. 
TABLE V

Summary of amounts of iodotyrosines determined in extracts of $100 \mathrm{ml}$ normal human serum or of pure human serum albumin from $100 \mathrm{ml} \mathrm{serum*}$

\begin{tabular}{|c|c|c|c|c|c|c|c|}
\hline \multirow[b]{3}{*}{ Source } & \multirow{3}{*}{$\underset{\text { Original serum no. }}{\text { Orext) }}$} & \multirow{3}{*}{$\begin{array}{c}\text { PBI† } \\
\text { (donor's } \\
\text { serum) }\end{array}$} & \multicolumn{5}{|c|}{ Amounts } \\
\hline & & & \multicolumn{2}{|c|}{$\mu \mathrm{g}$ iodine $/ 100 \mathrm{ml}$} & \multicolumn{3}{|c|}{$\%$ PBI } \\
\hline & & & MIT & DIT & MIT & DIT & Total \\
\hline \multirow{3}{*}{$\begin{array}{l}\text { Normal human serum } \\
\text { Human serum albumin }\end{array}$} & & $\mu \mathrm{g} / 100 \mathrm{ml}$ & & & & & \\
\hline & II & $\begin{array}{l}5.6 \\
6.4\end{array}$ & $\begin{array}{l}0.63 \\
0.81\end{array}$ & $\begin{array}{l}0.45 \\
0.56\end{array}$ & $\begin{array}{l}11 \\
12\end{array}$ & $\begin{array}{l}8 \\
9\end{array}$ & $\begin{array}{l}19 \\
21\end{array}$ \\
\hline & $\begin{array}{l}\text { III } \\
\text { IVI } \ddagger \\
\text { VI (West) }\end{array}$ & $\begin{array}{l}6.2 \\
6.0 \\
5.8 \\
5.8 \\
5.9\end{array}$ & $\begin{array}{l}0.78 \\
0.74 \\
0.68 \\
0.82 \\
0.60\end{array}$ & $\begin{array}{l}0.63 \\
0.69 \\
0.56 \\
0.68 \\
0.63\end{array}$ & $\begin{array}{l}13 \\
12 \\
12 \\
14 \\
10\end{array}$ & $\begin{array}{l}10 \\
12 \\
10 \\
12 \\
11\end{array}$ & $\begin{array}{l}23 \\
24 \\
22 \\
26 \\
21\end{array}$ \\
\hline
\end{tabular}

* Values were corrected for losses.

$\dagger$ Mean of two determinations.

$\ddagger$ MIT and DIT values determined in the course of two dimensional chromatography and corrected for losses.

\section{Discussion}

The results of the present study indicate that materials indistinguishable from authentic mono- and diiodotyrosines can be extracted from normal human serum. These are referred to, subsequently, as iodotyrosines. Both iodotyrosines were calculated to be present together in serum extracts in a range of from 19 to $25 \%$ of the proteinbound iodine of the original serum. The identity of the compounds in the MIT and DIT areas of the chromatograms of whole serum extracts was tested by a procedure involving repeated two dimensional chromatography to constant specific activity.

The unknown materials suspected of being iodotyrosines did maintain a constant specific activity throughout, which varied between the initial and second two dimensional chromatograms by only 1 to $7 \%$. Furthermore, destruction of the organic matrix of these compounds and subse-

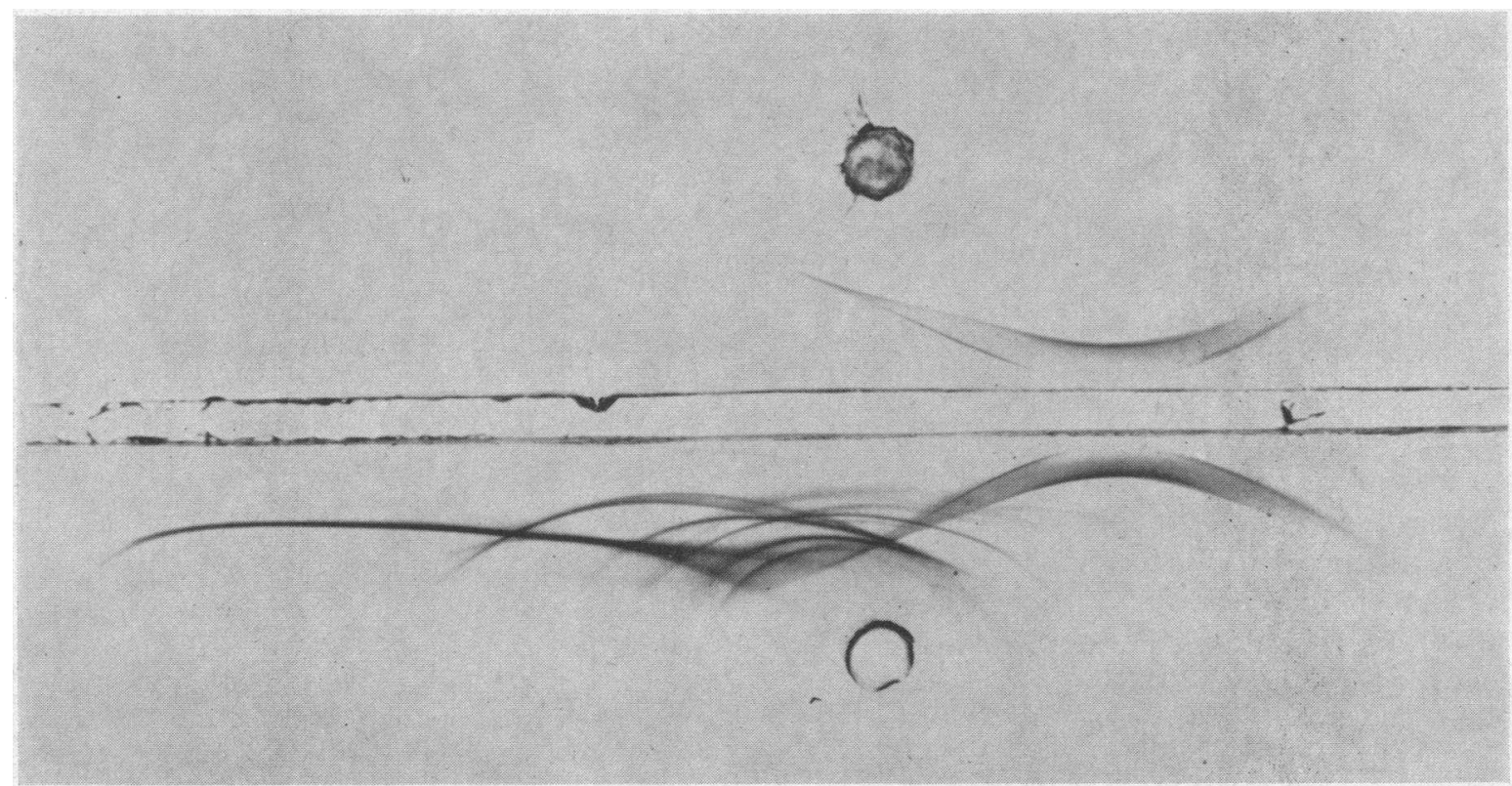

Fig. 5. IMMUNOELECTROPHORETIC PATTERN SHOWING PURITY OF ALBUMIN FRACTION OBTAINED FROM NORMAL HUMAN SERUm by Porath colum electrophoresis and countercurrent elution. The albumin fraction was placed above, and normal human serum below, the well containing antihuman caprine serum. 
quent distillation was accomplished in the Barker wet ash procedure for protein-bound iodine determination, and established that these materials were in fact iodinated ones.

Fractionation of normal human serum into its basic protein components, and subsequent extraction of each of these protein fractions, demonstrated that MIT and DIT were associated with the albumin fraction only. Both $\mathrm{MIT}^{-127} \mathrm{I}$ and DIT ${ }^{127}$ I precipitated with the albumin fraction and did not pass through a dialysis membrane in detectable amounts. Thus, the iodotyrosines were either protein bound but extractable from this protein or were present as a different type of labile precursor that yielded the free compounds upon extraction. In either event, circulation of MIT and DIT in a bound or precursor state eliminates the kinetics objections to the proposal that iodotyrosines are normal constituents of the serum iodine.

Losses of MIT and DIT have been estimated in three ways (Table IV) : from losses of ${ }^{131}$ I-labeled MIT and DIT added to the albumin fraction subsequent to electrophoresis, from the losses during the entire procedure of labeled thyroxine added to the original serum, and from total ${ }^{127} \mathrm{I}$ determined for the original serum and for the eluates of the final chromatograms. There is some difference between the losses from method I and thin layer procedure, but losses of iodotyrosines and of labeled $\mathrm{T}_{4}$ closely approximate each other. Thus correction for losses to obtain values for 100 $\mathrm{ml}$ serum seems justifiable. The iodotyrosines then represent approximately 19 to $25 \%$ of the extractable iodine from serum or purified serum albumin.

The reported failures to detect iodotyrosines in extracts of normal human serum can be attributed to two factors: incomplete destruction, if at all, of serum proteins, and the use of amounts of serum too small to allow these compounds to be demonstrated. For example, in $2 \mathrm{ml}$ of normal human serum there is an estimated total of $0.03 \mu \mathrm{g}$ of MIT and DIT. After losses in extraction and chromatography, insufficient iodide is left to activate the Sandell-Kolthoff catalytic reaction.

The objection also can be rejected that organic, or inorganic, artefacts are responsible for the apparent presence of iodide, as detected colorimetrically, in the iodotyrosine regions of the chromato- grams. Both types of artefacts are excluded by the results from the Barker wet ash procedure above. The possibility of organic artefacts also has been eliminated by the work of Row, Volpé, and Ezrin (22) with Postmes' ferric ferricyanide method (47).

The failure of numerous efforts to label iodotyrosines in vivo in animals or man has recently begun to be overcome. Labeling of iodotyrosines in rats has been accomplished by daily feeding of $\mathrm{Na}^{-125} \mathrm{I}$ over a period of 60 to 100 days (38). The labeled iodotyrosines were not found in free form but were shown to remain with the serum proteins during separation by Sephadex G-25 and column chromatography. Labeling has also been achieved with ${ }^{129} \mathrm{I}$ fed chronically to equilibrium. About a third of the organic iodine was present as MIT and DIT in one study (48) but only $1 \%$ to $2 \%$ in the other (39). These studies indicate the prolonged time and high dosages which are required for successful labeling and which, in man, would not be permissible because of radiation danger.

The nature of the parent compound in normal human serum from which iodotyrosines are extracted awaits elucidation, as does the physiological significance of these compounds.

\section{References}

1. Trevorrow, V. Studies on the nature of the iodine in blood. J. biol. Chem. 1939, 127, 737.

2. Wilmanns, $H$. Bestimmung und Bedeutung verschiedener Jodfraktionen in Biologischen Material. Z. ges. exp. Med. 1943, 112, 1.

3. Tong, W., A. Taurog, and I. L. Chaikoff. The metabolism of $\mathrm{I}^{131}$-labeled diiodotyrosine. J. biol. Chem. 1954, 207, 59.

4. Fletcher, P. E., J. Litvak, and J. B. Stanbury. The capacity of normal man to deiodinate iodotyrosine. Acta endocr. (Kbh.) 1958, 29, 307.

5. Gross, J., and C. P. Leblond. The presence of free iodinated compounds in the thyroid and their passage into the circulation. Endocrinology 1951, 48, 714.

6. Gross, J., and C. P. Leblond. Metabolites of thyroxine. Proc. Soc. exp. Biol. (N. Y.) 1951, 76, 686.

7. Gross, J., C. P. Leblond, A. E. Franklin, and J. H. Quastel. Presence of iodinated amino acids in unhydrolyzed thyroid and plasma. Science 1950, 111, 605.

8. Gross, J., and R. Pitt-Rivers. The identification of $3: 5: 3^{\prime} \mathrm{L}$-triiodothyronine in human plasma. Lancet $1952,1,439$. 
9. Laidlaw, J. C. Nature of the circulating thyroid hormone. Nature (Lond.) 1949, 164, 927.

10. Rosenberg, I. N. The nature of the circulating thyroid hormone in Graves' disease. J. clin. Invest. 1951, 30, 1.

11. Rall, J. E. Iodine compounds in the blood and urine of man. J. clin. Endocr. 1950, 10, 996.

12. Roche, J., and R. Michel. The nature, biosynthesis and metabolism of thyroid hormones. Physiol. Rev. 1955, 35, 583.

13. Taurog, A., and I. L. Chaikoff. The nature of the circulating thyroid hormone. J. biol. Chem. 1948, 176, 639.

14. Taurog, A., I. L. Chaikoff, and W. Tong. The nature of plasma iodine as revealed by filter paper partition chromatography. J. biol. Chem. 1950, $184,99$.

15. Werner, S. C., and R. J. Block. Discrepancy between the distributions of iodine in human serum when estimated by iodine-131 and iodine-127. Nature (Lond.) 1959, 183, 406.

16. Block, R. J., S. C. Werner, and R. H. Mandl. A method for the investigation of the distribution of radioiodine in the serum after small test doses of $\mathrm{I}^{131}$. Arch. Biochem. 1958, 73, 9.

17. Block, R. J., S. C. Werner, R. H. Mand1, V. V. Row, and I. Radichevich. The probable presence of diiodotyrosine and of monoiodotyrosine in human serum. A discrepancy between the distribution of iodocompounds when estimated by $\mathrm{I}^{131}$ and by $\mathrm{I}^{127}$. Arch. Biochem. 1960, 88, 98.

18. Stanbury, J. B., A. A. H. Kassenaar, and J. W. A. Meijer. The metabolism of iodotyrosines. I. Fate of mono- and di-iodotyrosine in normal subjects and in patients with various diseases. J. clin. Endocr. 1956, 16, 735.

19. Kono, T., L. Van Middlesworth, and E. B. Astwood. Chemical identification of iodine-containing compounds in human serum. Endocrinology 1960, 66, 845.

20. Dimitriadou, A., T. R. Fraser, J. D. H. Slater, and P. C. R. Turner. Staining for iodine in chromatograms of human plasma: an artefact due to thiourea or thiouracils. Nature (Lond.) 1960, 187, 691.

21. Werner, S. C., and I. Radichevich. Presence of iodine-127 iodotyrosines in extracts of normal human serum. Nature (Lond.) 1963, 197, 877.

22. Row, V. V., R. Volpé, and C. Ezrin. ${ }^{127}$ I-iodotyrosine-like compounds in normal human serum. Clin. chim. Acta 1966, 13, 666.

23. Wynn, J. Organic iodine constituents in human serum. Arch. Biochem. 1960, 87, 120.

24. Bird, R., and H. E. A. Farran. A sensitive method for the detection of iodinated compounds in human plasma, and its application in the study of thyrotoxicosis. J. clin. Endocr. 1960, 20, 81.

25. Wellby, M. L., and B. S. Hetzel. Demonstration of iodotyrosines in human plasma in response to thyroid stimulation. Nature (Lond.) 1962, 193, 752.
26. Pileggi, V. J., H. A. Segal, and O. J. Golub. Determination of organic iodine compounds in serum. III. Iodotyrosines in normal human serum. J. clin. Endocr. 1964, 24, 273.

27. Nauman, J. The study of iodoamino acids in hyperthyroidism. Warsaw, Poland, National Medical Publishing House, 1965.

28. Galton, V. A., and R. Pitt-Rivers. A quantitative method for the separation of thyroid hormone and related compounds from serum and tissues with an anion-exchange resin. Biochem. J. 1959, 72, 310.

29. Arosenius, K. E. Studies on the iodoamino acids in blood serum. Acta Soc. Med. upsalien. 1963, 68, 215.

30. Stark, H., and D. Knorr. Zur Bestimmung von Schildruesenhormonen auf Papierchromatogrammen durch Neutronenaktivierung. Atomenergie 1961, 10, 408.

31. Kellershohn, C., D. Comar, and C. LePoec. Détermination de l'iode sanguin par analyse d'activation. Int. J. appl. Radiat. 1961, 12, 87.

32. Dimitriadou, A., P. C. R. Turner, and R. Fraser. Activation analysis of paper chromatograms for iodine (iodine-127 $\rightarrow$ iodine-128). Nature (Lond.) 1963, 198, 576.

33. Dimitriadou, A., R. Fraser and P. C. R. Turner. Iodotyrosine-like substances in human serum. Nature (Lond.) 1964, 201, 575.

34. Pitt-Rivers, R., and J. E. Rall. Radioiodine equilibrium studies of thyroid and blood. Endocrinology 1961, 68, 309.

35. Lissitzky, S., J. Bismuth, and C. Simon. Absence of free iodotyrosines from the plasma of the rat. Nature (Lond.) 1963, 199, 1002.

36. Ermans, A. M., J. Kinthaert, R. Calay, F. Goossens, and P. A. Bastenie. Etude sur le métabolisme de l'iodide intrathyroidien et sur le nature de l'hormone circulante dans le goitre simple. Probl. actuel. Endocr. Nutr. 1964, 8, 233.

37. Dunn, J. T., and S. C. Werner. Metabolism of L-thyroxine $\left(3: 5-{ }^{131} \mathrm{I}\right)$ in man. J. clin. Endocr. 1964, 24, 460.

38. Radichevich, I., and S. C. Werner. In vivo labelling of extractable iodotyrosines in serum of rat and dog. Proc. Soc. exp. Biol. (N. Y.) 1967, 124, 1009.

39. Rhodes, B. A., and H. N. Wagner, Jr. Are iodotyrosines normal constituents of plasma? Nature (Lond.) 1966, 210, 647.

40. Radichevich, I., and S. C. Werner. Unpublished work.

41. Porath, J. Column electrophoresis on a large scale. Science Tools, LKB Inc., 1964, 11, 21.

42. Grabar, P., and C. A. Williams. Electrophoretic and immunochemical properties of a mixture of proteins. Biochim. biophys. Acta 1953, 10, 193.

43. Lowry, O. H., N. J. Rosebrough, A. L. Farr, and R. J. Randall. Protein measurement with the 
Folin phenol reagent. J. biol. Chem. 1951, 193, 265.

44. Mandl, R. H., and R. J. Block. Methods for the qualitative, semiquantitative, and quantitative determination of iodoamino acids and of inorganic iodide in iodoprotein digests and in human serum. Arch. Biochem. 1959, 81, 25.

45. West, C. D., V. J. Chavre, and M. Wolfe. A serum thyroxine method: application in thyroid disease and iodine-treated patients. J. clin. Endocr. 1965, $25,1189$.
46. Barker, S. B. Determination of protein bound iodine. J. biol. Chem. 1958, 173, 715.

47. Postmes, T. J. L. J. Differentiation between iodine and noniodine spots on paper chromatograms during the microquantitative determination of the iodinated amino acids of human serum. Clin. chim. Acta 1964, 10, 581.

48. Oullette, R. P., J. F. Balcius, and K. Zuppinger. The determination of iodine-containing compounds by neutron activation of I-129. Int. J. appl. Radiat. 1966, 17, 649. 